\title{
Hope of the Future: Indigenous Children Perspectives about Education
}

\author{
Jennifer M. Arbiol \\ University of Southeastern Philippines, \\ Davao City, Philippines \\ Elisa Mae Gura, Rey Jan Pusta and Laurence Cece \\ University of Southeastern Philippines, \\ Davao City, Philippines
}

\begin{abstract}
The study investigates the perspectives of indigenous children about Education. It seeks to understand the experiences of the indigenous children in school and their issues and concerns in schooling. The two basic ideas in the study of perception and Bronfenbrenner's Ecological Systems Theory provide theoretical foundations for the participants' experiences and concerns. Participatory action research and phenomenological methods were utilized in conducting the study. Four (4) children of indigenous people and 5 of the parents participated in the study. Purposive sampling was used to identify the participants. Data were analyzed using thematic analysis. Findings of the study show that the participants, especially the children, desired to finish their Education. Nevertheless, they have to stop schooling from working and helping their parents provide for the family's needs. The issues and concerns identified by the participants revolve around the family condition means of transportation going to school, teachers in school, discrimination, and practices of indigenous people.
\end{abstract}

Keywords: hope, perception, indigenous children, Education

\section{Introduction}

Indigenous people comprised $5 \%$ of the global population, but approximately $15 \%$ is at the bottom of human well-being index ratings; and one of the critical causes is the lack of quality education that is well-resourced, culturally sensitive, aligned with their learning needs, languages, priorities, and aspirations (Cosentino, 2016). In the Philippines, as of 2015, there are approximately 11 million indigenous people across the region based on the National Commission's report on Indigenous People ("Indigenous Peoples of the Philippines," 2015). The Special Division for Inclusive Social Development Indigenous People of the United Nations have identified issues concerning the Education of indigenous people such as a gap in Education due to lack of respect and resources; obstacles to Education like bullying, arriving in school hungry; loss of identity; invisible and at risk especially the unregistered children; and irrelevant of Education as it promotes competition rather than the communal way of living (UNDESA, 2018). Furthermore, 
discrimination in schools due to ethnicity is the major obstacle to equal access to education that leads to poor performance and higher dropout rates (UNDESA, 2018).

In the Philippines, an article published in a local newspaper commented about the historical abuses, discrimination, and marginalization suffered by indigenous people. They have experienced harassment and other injustices in their communities that affected their Education (Rabago-Visaya, 2016). In Davao City, there are 11 tribes, namely: Kagan, Maguindanaon, Maranao, Sama, Tausug, Iranun, Ata, Klata/Giangan, Matigsalog, Ovu Manuvu, and Tagabawa (Badian, 2016). Badian (2016) commented in his article that many indigenous people are still excluded from society and their rights as citizens are deprived; despite this, the leaders want their young generation to be educated to improve their community.

In 2007, The Asian South Pacific Bureau of Adult Education (ASPBAE) reported that indigenous children are disadvantaged with lower educational attainment, lower enrollment rates, and higher school dropout rates. A study conducted by Cornelio and De Castro (2016) shows that state and non-state actors' collective endeavors in establishing schools and programs and formulating indigenous peoples' policies are considerably sluggish; their implementation is yet to be seen and tested.

Children need to discover their potentials. Nussbaum (2011) postulates that human development entails the unfolding of powers that human beings bring into the world. Moser (1989) contends that gender and development strategies in the Third World economies emphasize men's voices. Children, to some extent, are unrecognized, and they are dependent on the care of women (Kabeer, 2003). They are not able to discover their potentials. Nussbaum (2011) suggests that promoting capabilities entails Education provided by a society that gears towards fostering 'internal capabilities,' such as the children's capacity to assert their physical and emotional needs. Moreover, McIntyre-Mills and de Vries (2013) proposed several ways in which the change of emphasis in formal Education could take place in order to foster the children's well-being by encouraging them to connect with others and providing a sense of community that enables them to adapt.

In this paper, it is contended that indigenous children, at some point, are not able to realize their capabilities in formal Education. The goal of the study is to explore the views of indigenous children in Education. It is a phenomenon that needs to be given importance through research considering that children, no matter their ethnicity, are primarily the future of the country. This paper explores the experiences and concerns of indigenous children in formal education.

Children of Indigenous People have the potential that they can discover through Education. The primary objective of the study is to explore the perspectives of the indigenous children about Education. Specifically, to understand the children's experiences in school and to look into the issues and concerns of children in schooling. It also explores the reasons why indigenous children drop out of school. Based on the objectives, the research questions are (1) what are the experiences of the indigenous children in school?; (2) what are the issues and concerns of the indigenous children in schooling?

The purpose of the study intends to enlighten the policymakers, specifically the Department of Education, to look into the conditions of the indigenous children. They can utilize the study's findings to formulate policies in improving the welfare of the indigenous children in schools, particularly the participants of the study.

\section{Review of Literature}

Studies about indigenous people generally depict that schooling goals for indigenous children have not changed, and they are still focused on the assimilation of Native students into the mainstream (Tomkins, 2002). Indigenous people have been at the forefront in arguing for better treatment, recognition of and restitution for historical justices, and recognition of self-determination or 
autonomy (May, 2003). A study conducted in Canada about indigenous people recommends six specific activities for educators: monitor the phenomenon of discrimination, adjust time requirements of individuals to suit community exigencies, incorporate cultural Education of language in school curricula, address familial and community exigencies in the programs and services, improve teacher quality, and inform students in rural areas about the reality of postsecondary Education (Schissel, Wotherspoon, \& Friesen, 2002).

A growing body of literature emphasizes community and culture-based education to meet the educational need of indigenous children (Brayboy \& Castagno, 2009). Indigenous children who participated in an intervention of acceptable teaching practices that incorporated improvement in self-esteem and culturally-relevant teaching lessons display more positive self-esteem and locus of control (Rubie, Townsend, \& Moore, 2004). This shows the importance and effectiveness of using culturally relevant teaching practices (Rubie, Townsend, \& Moore, 2004).

Many of the indigenous children in Latin America are poor who hardly have access to formal and stable schooling; thus, mobile technology was considered to meet the learning needs of the children (Kima, Miranda, \& Olacireguic, 2008). Gray \& Beresford (2008) argues that the lack of progress in indigenous Education is a reflection of a complex set of underlying factors. Hence, there has to be a new governance model for indigenous education, involving horizontal and vertical policy-making structures. Santoro, Reid, Crawford, \& Simpson (2011) conducted a study about indigenous children in Australia and argued about teachers and policymakers' need to listen and learn from indigenous teachers to establish shared understandings and assumptions about indigenous learners. There is a need to develop a radical pedagogy that responds to indigenous people's culture since indigenous people are in educational crises; therefore, indigenous educators and teachers must be trained to be agents of change (Smith, 2003).

Klenowski (2008) argued that teachers need to distinguish the "funds of knowledge" that indigenous students draw from. The teachers also need to take on a culturally responsive pedagogy to open up the curriculum and assessment practice in allowing different ways of knowing and being. A study in Canada suggests that aboriginal early childhood programs should incorporate aboriginal pedagogy, be infused with aboriginal language and culture, and be adequately staffed by qualified aboriginal educators to empower aboriginal communities (Preston, Cottrell, \& Pelletier, 2012).

In the Philipines, local schools set up by indigenous leaders in partnership with non-government organizations (NGOs), and religious organizations have encountered problems with bureaucracies in the government concerning national standards and financial inadequacies (Cornelio \& De Castro, 2016). In 2016, the Indigenous People International Centre for Policy Research and Education reported that indigenous people are the least served in terms of access to Education, and they recommended that the Department of Education should increase their investment for inclusive Education to make sure that educational programs will reach the indigenous communities.

The studies presented highlight the need to understand indigenous learners to provide appropriate educational programs suitable for their culture and learning styles. It is still an unrelenting issue among indigenous children to be in the mainstream as they have to develop their potentials vis a vis helping their community preserve their culture.

\section{Theoretical Framework and Conceptual Framework}

The two basic ideas in the study of perception are the bottom-up process and the top-down process. The bottom-up process starts at the lowest sensory levels of the most distant cognitive apparatus levels and then gradually leads to a more complicated set of processes, which take place 
in higher cortical structures that are responsible for more global and abstract ways of thinking (Demuth, 2013). Meanwhile, the top-down process proposes that in order to process a sensory stimulus, one needs to have prior experience or knowledge, or other influences which help to organize and form cognitive contents (Demuth, 2013).

Furthermore, the study is also anchored on the theory of Bronfenbrenner's Ecological Systems Theory. The theory postulates that his/her environment influences the child's growth and development (cited in (Paquette \&Ryan, 2001). As cited by Paquette \& Ryan (2001), Bronfenbrenner identified five different layers of the environment that affect the child's growth and development. The five layers are the microsystem, mesosystem, exosystem, macrosystem, and chronosystem. They described each of the five layers as follows: The microsystem is the most influential among the five layers since it includes the child's significant others such as the family, school, peers, and neighborhood. The microsystem includes those with a direct connection with the child. The mesosystem is the relationship between the child's microsystem structures - For instance, the relationship between the child's parents and his/her teachers. The exosystem is comprised of a more extensive social system where the child does not have direct contact. This includes the work schedule of his/her parents, the community-based resources of the family, etc. The macrosystem is the outermost layer of the child's environment. This comprises the culture of his/her parents, laws, and others. The chronosystem denotes the dimension of time that recounts the child's environment. An example of this is the timing of the child's parents' death and the physiological changes that the child experiences as he/she grows up. The child's interaction with his/her environment influences his/her growth and development.

Based on the above discussions, the study proposes that indigenous children's perspectives are based on their experiences, issues, and concerns about Education. The two basic processes, the bottom-up and top-down process in perception, are their enabling mechanisms in forming their perspectives about Education. The perspectives are formed by their experiences as well as the issues and concerns that they encounter. It is further assumed that their environment that consists of the five layers identified by Bronfenbrenner's Ecological Systems influences their experiences. Figure 1 shows the schematic diagram of the study. The perspectives refer to the children's views about Education, which is formed by their experiences, issues, and concerns. The experiences are the day to day encounter of the children with their environment, which affect their functioning. Meanwhile, the issues and concerns are the problems that the children have to deal with as they interact with their environment.

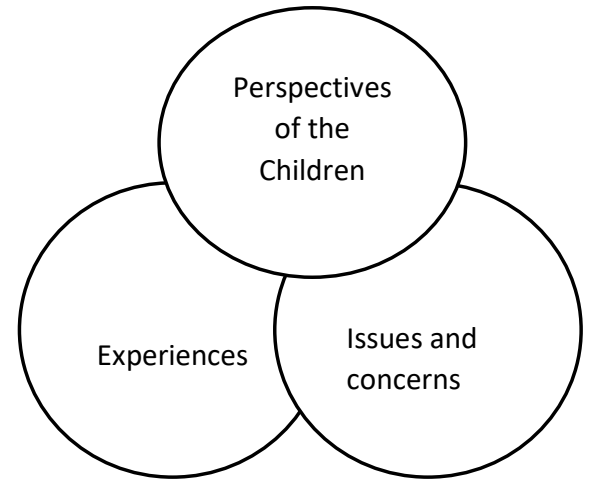

Figure 1. Schematic Diagram of the Perspectives of the Children of Indigenous Peoples about Education 


\section{Methods}

\section{Design}

The study used Participatory Action Research (PAR) to co-identify the ways to explore the perspectives of the indigenous children's education in the Southern Part of the Philippines. PAR is a method of inquiry-based on social transformation and is often used in developing countries (Mertens, 2010). The study also used the Phenomenological Method to gather information about the experiences of the children in school and their issues and concerns in schooling. It provides a total picture of several individuals who have experienced the same phenomenon (Creswell, 2014; Neuman, 2014). Interviews are commonly used in gathering the data (Creswell \& Creswell, 2018; Yin, 2011).

\section{Participants}

The study conducted key informant interviews and focus group discussions with the members of the participants' community. The participants were asked to answer the question, "What are their perspectives in schooling?" The purposive sampling technique was used to identify if the participants were indigenous children. Furthermore, to provide an in-depth understanding of the study, the parents were interviewed. The data were gathered with the help of the gatekeeper from the Barangay. Four children and five parents were interviewed. The average age of the children is 17, with two males and two females. The average age of the parents is 46 . There were four mothers and one father who participated. The participants belong to the indigenous people community located in the Southern part of the Philippines Region XI.

\section{Measure}

An interview questionnaire was developed in order to gather the responses of the participants. The interview form consists of the participants' profile and the eight questions about the participants' perspectives about Education.

\section{Procedures}

The data were gathered through collaboration with a non-profit organization working with indigenous people. Permission was sought through the barangay captain, who helped in the identification of the participants.

Informed consent and assent were guaranteed in gathering the data. This is to make sure that participation in the study was voluntary. Other ethical considerations, such as confidentiality, were ensured in the reporting of the data. This is to protect the privacy of the participants. The researcher interviewed the participants of the study. A meso-level approach was used in analyzing the data from multiple sources. Thematic analysis was also used to analyze the gathered data.

\section{Results and Discussions}

The study explored the perspectives of indigenous children about Education. Specifically, it looked into the experiences and concerns of the participants.

\section{Experiences of the Participants}

The responses of the participants depict that life is complicated. Despite it, they enjoyed school. Moreover, life continues even after they dropped out of school, and they have kept their hopes and dreams.

All of the participants shared that life is complicated. The children stopped from schooling because of difficulty in life. Child 2 was able to reach high school but had to stop in 2018. [Her parents could not afford to provide for her needs], "kanang nakaundang ko kay tungod sa kalisod...dili kaya ma-afford ang among kinahanglan." [There were times that food is not enough for her family], 
"kanang usahay makulangan mig kanang pagkaon..." Child 1 has the same experience. He recalled [going home with no rice to cook], "usabay pag-uli sa balay kay walay bugas..." Furthermore, [he shared about going to school with no pens], "usahay walay mga ballpen." Child 3 also shared about their [financial problems], "kanang financial na problema." He reached Grade 8 but had to stop schooling in order to help his family. The father of Child 4 died at a young age. He has a stepfather, and her mother helped on the farm. She shared that ther family has no money to buy for the projects needed in school], ", ikapalit sa mga projects ana sir..."

The parents also shared the same sentiments with the children. Life is difficult. One of the parents recalled that they have to transfer from one place to another to work, "lisod jud ko maam kay ngano? Akong mga ginikanan murag walay klaro... magbalbinbalbin silag puyo gani...kiniraan man mao ran a wala ko kaeskwela kay wala may moatiman sa akoa... dayon didto na balbin nasad akong mama..." [Very difficult mam... why? My parents seem to lack direction...they transferred from one place to another...old fashioned that is why I could not study because there is no one to care for me...then my mother would transfer again...] - Parent 2. Parent 2 has reached Grade 4 and works at the farm. She has nine children.

The participants' experiences depict the same situation of the indigenous children in Latin America, who are poor and hardly have access to formal and stable schooling (Kima, Miranda \& Olacireguic, 2008). Furthermore, it shows that Bronfenbrenner's ecological systems theory, precisely his concept about the microsystem, affects the children's development in terms of Education. The microsystem includes the child's significant others, such as the family, and has a direct connection with the child (Paquette \& Ryan, 2001). Thus, the condition of the parents affected the children's opportunity for Education.

Despite the difficulty in life that the participants have experienced, they recalled happy memories in school. Indeed, they also enjoyed school. Child 4 expressed that [she liked school very much and hopes to finish], "ganahan kayo sir...unta...gusto jud unta ko makahuman ug eskwela sir..." She enjoyed school, mainly when their class organizes a [Christmas Party, exchange gifts and receive gifts from their teacher], "kanang pareha anang magkuan sir murag Christmas party mi....ma enjoy pud mi sir...maghinatag kami kuan sir regalo... ang among teacher kay daghan kay kuan...daghan ipanghatag sa amoa..." Child 2 was happy to attend school so [she could achieve her ambitions], "kanang kuan nalipay ko kanang nakaeskwela ko kay para gusto nako matuman akong pangarap..." She also enjoyed [learning how to read in the English subject and speak the language by going to school], "gustuban nako sa eskwelahan kay kanang nabunabuna nako na kanang eskwelaban kay kanang makatuon ug pagbasa...kanang makatuon tanan English then ug tanan..." Moreover, she also [learned in school to respect her parents and everybody], "ug sa eskwelhan nakatuon pud ko sa pagrespeto sa kuan sa ginikanan ug para sa labaw sa tanan... "Child 3 shared that [she likes her teacher because she is kind], "ganaban pud ko sa among maestro... but-an..."

The parents also enjoyed going to school. Parent 4 recalled that [she enjoyed being the leader of their class. She also got to learn and enjoy singing in school], "ma enjoy ka tungod moleader ko sa akong kauban...ikaduba mam ka na pud kabalo ko mokanta kanang didto ko moenjoy..." She also [expressed her joy when she received recognition for performing well in class, and her mother was the one who went to the stage to pin the ribbon on her], "malipay man ta basta nay ribbon... malipay pud atong mama kay makasaka ug stage..." Parent 2 [found joy learning in the subjects English and Filipino], "naganahan pud ko mam katong moeskwela ko...kana bitaw subject na English...Filipino..."

Based on the responses of the participants, it shows that the school is influential in the child's life (Paquette \& Ryan, 2001). It is part of the participants' microsystem as their lives have been transformed from the learnings that they acquire and connections that have been formed with their classmates and teachers. 
The children continue to cope in life after they left school. Child 1 [left school in order to help his parents and his younger siblings who are studying], "undang na gyud mam...makatabang ko sa akong ginikanan para mga maghud na lang nako ang paeskwelahon..." His parents separated because his father had an extramarital affair. He had five step-siblings with his father's. He also thelped them with their livelihood by harvesting vegetables], "kanang tabang-tabang sa pangkinabubian... usabay hagbas ug gulay..." Child 2 also [left school to focus on selling vegetables to sustain her needs], "kanang nangita kog way makaeskwela ako kanang mang-guna gulay para mabaligya para maikapalit..." As part of the microsystem of the children, they stopped schooling in order to help their families. Indeed, the family has a significant role in their lives.

\section{Issues and Concerns of the Participants}

The participants' concerns when they were in school include the economic condition of the family, the distance between the school and their homes, their experiences of discrimination, their teacher, and the practices.

The primary means of living of the parents of the participants is farming. The family's economic condition shows that the income from farming is not enough to sustain the needs of the children, especially in pursuing their Education. There would be times that Child 1 would [go home with no rice], "usabay pag-uli sa balay kay walay bugas." He would be [absent from school whenever they have no rice to eat], "usabay maka absent pud mi...pagkaadlaw ka makabugas pud pagka-ugma makaeskwela." Likewise, Child 2 [stopped from studying because the family could not afford to send her to school even if she likes to study], "ay kanang di nila...kay dili man kaya sa akong ginikanan mapa-eskwela mi...kanang kursonada unta ko moeskwela." Even if Child 4 wants to study, [her parents could not provide for their school expenses, such as the projects needed in school], "walay ikapalit sa mga projects ana sir... usahay pud makulangan sa tungod kay pag-uma ra man among mama."

One of the parents recounted that even if [he wanted to study, his mother showed no concern about his Education as his family kept on transferring from one place to another, wherever they could find work], "desidido jud unta ko moeskwela maam sa una tungod sa among katigulangan namo ang akong mama kay kanang wala jud sa buna-buna nila ang pag-eskwela kay bisag asa ra man mi magpuyo... balbin-balhin ug trabaho.”-P3

The problem of transportation is one of the reasons that they have to stop schooling. The participants have to walk early morning to go to school. Then, in the afternoon, they have to walk again to get home. Child 2 shared that her school is 8 kilometers away from her school, and she had to walk the distance each day. The need to continually walk the long distance both in the morning and in the after caused her to be discouraged from going to school], "kay layo among eskwelahan...layo pa man among lugar sitio...pasulod 8 kilometers ginabaktas namo usahay kanang madiscourage kog eskwela kay kanang kada adlaw buntag, hapon magbaktas mi pauli sa amoa." Similarly, Child 3 shared that [their house is far from school], "kuan kanang layo sa amoa." Child 1 [felt sad that when he cannot go to school because there is no transportation], "naguol ko maam kay baseg di ko makaesk.wela maam... way sakyan maam."

The children's transportation problem was also the problem of their parents before as Parent 1 shared that [she had to walk from the farm to the city to go to school], "sa una baklayon jud didto sa bukid padung sa city."

One of the participants, on the other hand, had a concern with his teachers. Child 1 remembered [his teacher as strict and reprimanded him whenever he arrived late in school], "mga maestra maam mga maldita...usabay kanang sige rag kalate...kasab-an." He was always late because even if he wakes up early, he still had to walk whenever there was no available means for transportation. 
The development of the child is influenced by the environment (Paquette \& Ryan, 2001). The living condition of the children depends on the work of the parents. The children were not able to pursue Education because their parents could not afford to send them to school despite the government's offer of free Education. Besides, transportation was also a problem, although there were motorcycles available. Motorcycles could either be unavailable or too costly, especially during the rainy season, so the children would have difficulty attending school. As part of the child's microsystem, the teacher has a direct connection and influence on the child's growth and development (Paquette \& Ryan, 2001). The experience of Child 1 with the teacher had an impact on his perspective of Education. Prior experience or knowledge helps in organizing and forming cognitive content (Demuth, 2013).

The participants also experience discrimination. As Child 4 recounted that [she felt humiliated by her classmates because of how they discriminated her tribe], "kuan sir kanang binawayon nila ang tribo sir." Child 1 also felt the same way when [he heard criticisms about how her family could not afford to buy slippers when they saw him wearing torn slippers], "usahay sawayon pud maam ba...ingnan na walay ikapalit ang ginikeanan putol ang tsinelas." Furthermore, he also experienced being belittled [when his lunch is dried fish], "kanang bulad ray sud-an ginasaway."

Parent 4 also mentioned discrimination. She [felt discriminated and ashamed when her tribe was called impolitely as "bagobo-bagobo]." [She was afraid to socialize with her classmates because she felt being discriminated for it and it was one of the reasons why she stopped from studying], "abi nimo maam kanang discrimination labis na kayo makita ka nga tribo ka discriminate jud ka "bagobobagobo... nya maulaw baya ta... maulaw jud ko makig kuan halubilo gusto ta mag-enjoy gina maliit man ka so mao diha ang number 1 nako wala kapadayon ug eskwela maam."

Rabago-Visaya (2016) commented on the discrimination experienced by indigenous people, which the participants also experienced. The discrimination experienced by the participants is part of the perspectives formed by most people towards indigenous people. The top-down process denotes that prior experiences form part of the cognition of the individual. Their previous experiences influence the perspectives of the participants.

Arranged marriages is also a practice among the elders of the participants. One of the parents shared that [her parents arranged her for marriage at 10]. It was the reason that she had to stop studying, "kinaiya sa mga tigulang sa una na mobuya...mao na ang rason ngano wala ko nakaeswela." The individual's culture is also part of her macrosystem. The participant's culture concerning arranged marriages sidetracked her from pursuing formal Education.

\section{Hopes and Dreams}

The children continue to dream even if they have already stopped studying. Child 1 [hopes to graduate to have a better life and be able to help others], "makagraduate...gusto ko na lambo... makagraduate unta ko para makatabang pud." In the same way, Child 2 hopes to finish school. She hopes to reach her dreams. Child 3 [dreams of a school with kind classmates], "mga estudyante mga but-an." It is also [the dream of Child 4 to finish school and find work to help her family and siblings. She dreams of becoming a teacher. She also hopes that the toilet in her school will be improved], "makahuman ug pag-eskwela then makakita ug maayo na trabaho... makatabang pud sa among pamilya...sa akong mga manghod..naa pud mga makuwang gamay...sa CR."

The Asian South Pacific Bureau of Adult Education (ASPBAE) in 2007 reported that indigenous children are disadvantaged with lower educational attainment, lower enrollment rates, and higher school dropouts. The participants' hopes and dreams to continue to study depict that they desire to unfold their potentials. Nussbaum (2011) suggests that promoting capabilities entails Education provided by the society that gears towards fostering "internal capabilities." The children's hope to finish their schooling shows that they perceive Education as a way to improve their well-being and 
lead them to connect with others and have a sense of community that enables them to adapt (McIntyre-Mills and de Vries (2013). The children also perceive Education as a means for them to improve their present condition to provide better means of living to their families.

\section{Conclusions}

The findings of the study depict the experiences of the participants. They hope to finish their Education, but their families' economic condition is not well enough to provide for their needs. Even though primary Education is free, the parents struggle to provide for their children's needs in terms of Education. In addition to this, the lack of transportation means, and the capability to even pay for these means demotivate the children to go to school so that these transportation concerns also affected their parents during their time. Also, the participants' discrimination is a manifestation of how society is still unable to accept differences, which only emphasizes the importance of the role that Education plays in teaching society how to perceive and deal with indigenous people appropriately. Despite all these struggles, the participants continue to hope that Education can improve their well-being. It is with this hope that Education can respond to their dreams.

\section{Limitations}

The study's methodological limitation implies that the participants' responses are specific to their context and experiences. It cannot be generalized to other indigenous communities in the region. The participants provided their experiences based on their present conditions.

\section{References}

Asian South Pacific Bureau of Adulty Education (2007). Mapping out disadvantaged groups in Education. Retrieved from https://files.eric.ed.gov/fulltext/ED533598.pdf

Badian, M. C. (2016, July 17). The hope of the city's indigenous peoples. Mindanao Times. Retrieved from http://mindanaotimes.net/the-hope-of-the-citys-indigenous-peoples/

Brayboy, B. M., \& Castagno, A. E. (2009). Self-determination through self-education: culturally responsive schooling for indigenous students in the USA. Teaching Education, 20(1), 3-53. https:// doi.org/10.1080/10476210802681709

Cornelio, J. S., \& de Castro, D. F. T. (2016). The state of indigenous Education in the Philippines today. Indegenous culture, Education and globalization: critical perspectives from Asia (pp. 159-179. Springer.

Cosentino, G. (2016, August 9). Indigenous peoples have a right to quality education. But so far, we've failed them. World Economic Forum. Retrieved from https://www.weforum.org/agenda/2016/08/indigenous-people-have-a-right-to-qualityeducation-but-so-far-we-ve-failed-them/

Creswell, J. (2014). Research Design: Qualitative, Quantitative, and Mixed Methods Approaches. Singapore: SAGE Publications, Inc.

Creswell, J. \& Creswell, J.D. (2018). Research Design: Quantitative, Qualitative and Mixed Methods Approaches $5^{\text {th }}$ Ed. California: SAGE Publications, Inc.

Demuth, A. (2013). Perception Theories.

Gray, J., \& Beresford, Q. (2008). A 'Formidable Challenge': Australia's Quest for Equity in Indigenous Education. Australian Journal of Education. Retrieved from https:// doi.org/10.1177\%2F000494410805200207

Indigenous Peoples International Centre for Policy Research and Education. (2016). Situation indigenous peoples in the Philippines.

Indigenous Peoples of the Philippines. (2015). National Commission on Indigenous Peoples. Retrieved from https://www.ncipro67.com.ph/indigenous-peoples-of-the-philippines/

Kabeer, N. (2003). Gender mainstreaming in poverty eradication and the millennium development goals : a bandbook for policy-makers and other stakeholders. London: Commonwealth Secretariat: International Development Research Centre. 
Kim, P., Miranda, T., \& Olaciregui, C. (2008). Pocket School: Exploring mobile technology as a sustainable literacy education option for underserved indigenous children in Latin America. International Journal of Educational Development, 28(4), 435-445.

Klenowski, V. (2008). Australian indigenous students: addressing equity issues in assessment. Teacbing Education, 20(1), 77-93. https://doi.org/10.1080/10476210802681741

McIntyre-Mills, J., \& de Vries, D. (2013). Part 2: Transformation from Wall Street to Well-being. Systems Research and Behavioral Sciences, 30(4), 444-469. https://doi.org/10.1002/sres.2133

Mertens, D. (2010). Research and Evaluation in Education and Psychology: Integrating Diversity with Quantitative, Qualitative, and Mixed Methods. Los Angeles: SAGE Publications, Inc.

Moser, C. (1989). Gender planning in the third world: meeting practical and strategic gender needs. World Development, 17(11), 1799-1825. http://dx.doi.org/10.1016/0305-750X(89)90201-5

Neuman, W.L. (2014). Social Research Methods: Qualitative and Quantitative Approaches $7^{\text {th }}$ Ed. UK: Pearson Education Limited.

Nussbaum, M. (2011). Creating capabilities: the buman development approach. London: The Belknap Press of Harvard University Press.

Rabago-Visaya, L. (2016). Right to Education for indigenous peoples. The Freeman. Retrieved from https://www.philstar.com/the-freeman/opinion/2016/08/13/1612964/right-educationindigenous-peoples

Rubie, C. M., Townsend, M. A., \& Moore, D. W. (2004). Motivational and academic effects of cultural experiences for indigenous minority students in New Zealand. Educational Psychology, 24(2), 143160. https://doi.org/10.1080/0144341032000160119

Paquette, D., \& Ryan, J. (2001). Bronfenbrenner's Ecological Systems Theory. Retrieved from https://dropoutprevention.org/wp content/uploads/2015/07/paquetteryanwebquest_20091110.pdf.

Preston, J. P., Cottrell, M., \& Pelletier, T. (2012). Aboriginal Early Childhood Education in Canada: Issues of Context. Journal of Early Childhood Education, 10(1), 3-18. https://doi.org/10.1177\%2F1476718X11402753

Santoro, N., Reid, J., Crawford, L., \& Simpson, L. (2011). Teaching Indigenous children: listening to and learning from indegenous teachers. Australian Journal of Teacher Education, 36(10). http://dx.doi.org/10.14221/ajte.2011v36n10.2

Schissel, B., Wotherspoon, T., (2002). The legacy of school for aboriginal people: Education, oppression, and emancipation. Ontario: Oxford University Press.

Smith, G. H. (2003). Indigenous Struggle for the Transformation of Education and Schooling. Paper presented at the Alaskan Federation of Natives (AFN) Convention, Alaska. Retrieved from http://www.rangahau.co.nz/assets/Smith,\%20G/indigenous_struggle.pdf

Tomkins, J., \& Indegenous Commentary, W. (2002). Learning to See What They Can't: Decolonizing Perspectives on Indigenous Education in the Racial Context of Rural Nova Scotia. McGill Journal of Education, 37(003). Retrieved from https://mje.mcgill.ca/article/view/8646

United Nations Department of Economic and Social Affairs-UNDESA (2018). Education.

Yin, R.K. (2011). Qualitative Research from Start to Finish. London: The Guilford Press. 


\section{Appendix}

\section{INTAKE INTERVIEW FORM}

Part I. PERSONAL PROFILE

Name:

Age:

Date of Birth:

Birthplace:

Birth Order:

Residence Address:

Contact Numbers:

Religious

Affiliation:

Part II. FAMILY BACKGROUND

Father's Name: Occupation:

Mother's Name: Occupation:

Siblings:

\begin{tabular}{|c|c|c|c|c|}
\hline Name & Date of Birth/Age & Status & Educational Attainment & Occupation \\
\hline & & & & \\
\hline & & & & \\
\hline & & & & \\
\hline & & & & \\
\hline & & & & \\
\hline & & & & \\
\hline & & & & \\
\hline & & & & \\
\hline & & & & \\
\hline
\end{tabular}


Part III. EDUCATIONAL BACKGROUND

\begin{tabular}{|l|l|l|l|}
\hline & Name of School/Course & $\begin{array}{c}\text { Years of } \\
\text { Attendance }\end{array}$ & $\begin{array}{c}\text { Year } \\
\text { Graduated }\end{array}$ \\
\hline Primary & & & \\
\hline Elementary & & & \\
\hline Secondary & & & \\
\hline
\end{tabular}

Part VI. Interview Questions

1. How do you feel going to school?

2. What do you like in school?

3. What do you dislike in school?

4. Describe your unforgettable memories in school.

5. What are the reasons that you go to school?

6. What are the problems that you encounter in school?

7. How do you cope with the problems in school?

8. What is your dream of a school like? 